\title{
Diabetes-associated dysregulated cytokines and cancer
}

\author{
Yong Wu ${ }^{1,2 *}$, Yanjun Liu ${ }^{3}$, Yunzhou Dong ${ }^{4}$ and Jay Vadgama ${ }^{1,2}$ \\ ${ }^{1}$ Division of Cancer Research and Training, Charles R. Drew University of Medicine and Science, Los Angeles, USA \\ ${ }^{2}$ David Geffen School of Medicine, University of California, Los Angeles, USA \\ ${ }^{3}$ Division of Endocrinology, Charles R. Drew University of Medicine \& Sciences, UCLA School of Medicine, Los Angeles, USA \\ ${ }^{4}$ Vascular Biology Program BCH3137, Boston Children's Hospital, Harvard Medical School, Boston, USA
}

\begin{abstract}
Epidemiological data demonstrate that patients with diabetes have an augmented risk of developing various types of cancers, accompanied by higher mortality. A number of mechanisms for this connection have been hypothesized, such as insulin resistance, hyperinsulinemia, hyperglycemia, and increased inflammatory processes. Apart from these potential mechanisms, several diabetes-associated dysregulated cytokines might be implicated in the link between diabetes and cancer. In fact, some inflammatory cytokines, e.g. TNF- $\alpha$, IL-6 and leptin, have been revealed to play important roles in both initiation and progression of tumor. Here, we depict the role of these cytokines in key events of carcinogenesis and cancer development, including their capability to induce oxidative stress, inflammation, their participation in epithelial mesenchymal transition (EMT), angiogenesis, and metastasis. Finally, we will also highlight the existing knowledge in terms of the involvement of these cytokines in different cancer types and comment on potential significances for future clinical applications.
\end{abstract}

\begin{abstract}
Abbreviations: AGC: Advanced Gastric Cancer, AMPK: AMPActivated Protein Kinase, AP-1: Activator Protein 1, BBL: Benign Breast Lesions, BC: Breast Cancer, BMI: Body Mass Index, CAC: ColitisAssociated Colon Cancer, CXCL16: C-X-C Chemokine Ligand 16, DM: Diabetes mellitus, EC: Endothelial Cell, EMT: Epithelial Mesenchymal Transition, FGF2: Fibroblast Growth Factor 2, HER2: Human Epidermal Growth Factor Receptor 2, HGF: Hepatocyte Growth Factor, IGF: Insulin-Like Growth Factor, IGT: Impaired Glucose Tolerance, IL-6: Interleukin 6, LINE-1: Long Interspersed Nuclear Element-1, MAPK: p38 Mitogen-Activated Protein Kinase, MIF: Macrophage Migration Inhibitory Factor, MMP: Matrix Metalloproteases, MS: Metabolic Syndrome, NSCLC: Non-Small Cell Lung Cancer, PAI-1: Plasminogen Activator Inhibitor-1, RNS: Reactive Nitrogen Species, ROS: Reactive Oxygen Species, SDF-1: Stromal Cell-Derived Factor-1, STAT3: Signal Transducer and Activator of Transcription 3, TLR4: Toll-like Receptor 4, TNF: Tumor Necrosis Factor, uPA: Urokinase Plasminogen Activator, VEGF: Vascular Endothelial Growth Factor, VN: Vitronectin.
\end{abstract}

\section{Introduction}

Diabetes mellitus (DM), the $12^{\text {th }}$ leading cause of death worldwide [1], is a severe and chronic health problem worldwide that disturbs human body's ability to utilize the energy in food. It can be classified into three major types: type 1 , type 2 , and gestational diabetes. DM can cause serious acute and chronic complications that adversely impact the quality of life and survival of the majority of people with this disease. Cancer is the 2nd primary cause of death globally [1]. A growing number of studies demonstrate a positive link between DM and the risk of cancer and cancer-related mortality [2]. Currently, the number of people lives with diabetes worldwide is 250 million and this figure anticipated to reach 380 million in 20 years. Accordingly, one can assume that even a slight increase in the cancer risk associated with diabetes may have significant consequences at the population level.

The association between diabetes and cancer was first hypothesized more than 70 years ago and identified in the 1960s in population-based studies [3]. More recently, a number of studies [4] indicate that some type of cancers develop more frequently in patients with diabetes (primarily type $2 \mathrm{DM}$ ), whereas others such as prostate cancer happens less often in patients with diabetes. Diabetes imparts the highest relative risks (about 2-fold or higher) for liver, pancreas, and endometrium cancer, and lower risks (about 1.2-1.5-fold) for colon and rectum, breast, and bladder cancer [3]. Lung cancer does not seem to be associated with an augmented risk in diabetes, and the evidence for kidney cancer and non-Hodgkin lymphoma is indecisive. At present, few studies have investigated links between type $1 \mathrm{DM}$ and cancer [3].

Despite their important clinical significance, the potential biologic links between these two diseases are poorly understood $[3,5]$, which elicits a tremendous challenge for patient care. Some perplexing factors that have common or site-specific relevance make it hard to precisely evaluate cancer risk in patients with diabetes. These factors comprise diabetes duration, diverse therapeutic drugs, variable levels of metabolic control, and the potential existence of chronic complications. Currently, the mainstream view proposes that the relationship may be attributed to the direct effects of diabetes, i.e. hyperglycaemia $[3,6]$ or alterations in fundamental metabolic conditions including insulin resistance and hyperinsulinaemia [3]. Hyperglycemia may contribute to increased cancer risk in diabetes via augmented oxidative stress and DNA damage $[7,8]$. Studies of the relationship between hyperglycemia and cancer risk have been conducted for a long time, nonetheless the

Correspondence to: Yong Wu, Division of Cancer Research and Training, Charles R. Drew University of Medicine and Science, Los Angeles, CA 90059, USA, Tel: (323) 563-4885, Fax: (323) 563-4889; E-mail: yongwu@cdrewu.edu/yongwu@ucla.edu

Key words: diabetes mellitus, cancer, cytokine, angiogenesis, inflammation

Received: Janaury 27, 2016; Accepted: February 12, 2016; Published: February 15,2016 
underlying mechanisms remain unconvincing. Insulin is a growth factor with important metabolic and mitogenic actions, and its effect on cancer cells is advanced by multiple mechanisms acting at the receptor or post-receptor levels. Hence, hyperinsulinemia, exogenous insulin or insulin analogs [9-13] most probably favors cancer in patients with diabetes. However, Mink et al. [14] found no relationship between insulin levels and breast cancer (BC) incidence. Moreover, Kabat and colleagues demonstrated that baseline levels of insulin and the insulin resistance index do not correlate with an elevated risk of colorectal/colon cancer [15]. In addition, elevated levels of insulin-like growth factor (IGF), steroid and peptide hormones, and inflammatory markers seem to play an important role in the association between these two heterogeneous and multifactorial diseases [2].

Recently, more and more attention has been given to the role of cytokine dysregulation in cancer initiation and progression. Cytokines are low-molecular-weight proteins synthesized by immune and stromal cells in response to several stimuli [16]. They mediate cell-tocell communication and control differentiation, proliferation, immune cell activation, cell survival, cell migration, as well as cell death [16]. High blood glucose plays a pivotal role in the immune activation of diabetes, thus intensely enhances circulating cytokine levels via an oxidative mechanism, and this effect is more prominent in patients with impaired glucose tolerance (IGT) [17]. Esposito et al. suggest that the IGT subjects have fasting plasma interleukin 6 (IL-6) and tumor necrosis factor (TNF-) levels much higher than control subjects [17]. A study evaluating the serum levels of cytokines, chemokines and adipokines simultaneously with BioPlex assay by Costantini et al. [18] reveals that IL-1 $\alpha$, IL-2R, IL-12, IL-18, MIF, insulin, leptin, PAI-1, HGF, glucagon, resistin and adipsin are elevated while ghrelin is declined in T2 DM patients versus healthy controls. TNF- $\alpha$ and IL- 6 are possibly the best characterized pro-tumorigenic cytokines. They were originally suspected to be implicated in cancer due to activation of the oncogenic transcription factors NF- $\kappa \mathrm{B}$, activator protein 1 (AP-1) and signal transducer and activator of transcription 3, also known as STAT3 in epithelial cells [19-22]. Afterwards, numerous other cytokines and stimuli were revealed to have pro-tumorigenic effects. In relation to diabetes-associated cancer initiation and progression, the current review discusses the involvement of dysregulated cytokines under the diabetic condition in carcinogenesis and cancer development, for future therapeutic purposes.

\section{TNF- $\alpha$ and Interleukin- 6 (IL-6)}

Previous studies have revealed augmented circulating levels of inflammatory cytokines TNF- and IL-6 in patients with diabetes [2327]. The plasma TNF- and IL- 6 are probably produced by activated leukocytes and adipocytes and vascular endothelial cells. TNF- and IL-6 are typical pro-inflammatory cytokines with a pro-tumorigenic effect.

It is well known that unsolved inflammation can result in cancer. TNF- $\alpha$ is a pro-inflammatory cytokine involved in carcinogenesis [28]. Persistent exposure to low concentration of TNF- $\alpha$ can prompt a tumor phenotype [29]. TNF- $\alpha$ facilitates tumorigenesis and cancer development via activating nuclear factor-kB [30] and increasing reactive oxygen species (ROS) and reactive nitrogen species (RNS) formation, which can trigger DNA damage [31]. TNF- $\alpha$ has more significant impact in the early stage of carcinogenesis, e.g. angiogenesis and invasion $[19,30]$. Kwong et al. incubated normal human ovarian epithelial cells with a sustained TNF- $\alpha$ dose and revealed emergence of a precancerous-like phenotype with structural and functional alterations, including overexpression of cancer markers, tissue disorganization and cell invasion [32]. In addition, persistent TNF- $\alpha$ exposure can promote tumor-forming sphere ability and expression of stem cell-transcription factors, thus inducing cancer stem cell phenotypes in oral squamous cell carcinoma [33].

Raised serum levels of IL- 6 can be detected in patients with prostate cancer, colorectal adenomas, breast cancer, B-cell lymphoma, and myeloma [34,35]. IL-6 signaling is an imperative regulator of breast cancer stem cells, driving the malignant phenotype via differentiation and development of therapeutic resistance [36]. In addition, IL-6 strongly stimulates proliferation and growth of various cancer cell lines or primary tumors [37-39]. Notably, it has emerged as a biomarker for distinct inflammatory conditions and also a malignancy predictor, with sensitivity and specificity of approximately $60-70 \%$ and $58-90 \%$, respectively $[40,41]$. Generally, tumor-bearing patients or animals with increased levels of IL-6 in serum or tissue have a poor prognosis [21,4244]. Diminution of IL-6 signaling pathway during tumor induction contributes to a reduction in tumor multiplicity and growth $[45,46]$.

IL-6 binds to its receptor IL-6Ra and co-receptor gp130 (glycoprotein 130), hence stimulating the JAK/STAT signaling pathway [47]. A number of studies have underlined the role of the IL-6/JAK/STAT pathway in tumor initiation and progression because STATs are transcription factors directly involved in tumorigenic processes [48,49]. Moreover, IL-6 may prompt tumorigenesis by hypermethylating tumor suppressor genes and hypomethylating long interspersed nuclear element-1 (LINE-1) in oral squamous cancer cell lines [50]. In addition, IL-6 converts noncancer cells into cancer stem cells, promoting tumor invasion and expansion. Particularly, Kim et al. suggest that noncancer stem cells can secrete IL-6, which activate the IL-6R/JAK/STAT3 pathway, leading to increase in Oct4 gene expression [51].

According to aforementioned studies, IL- 6 can be used as a therapeutic target for cancer treatment. Several antibodies against IL-6/IL-6R are presently evaluated in phase I/II clinical trials aimed to develop of therapeutic substitutions. An anti-IL-6 monoclonal antibody, Siltuximab (CNTO 328), has presented hopeful outcomes for ovarian cancer, prostate cancer, non-small cell lung cancer (NSCLC) and multiple myeloma [52-56]. Tocilizumab, a humanized recombinant monoclonal IL-6 receptor (IL-6R) antibody has been analyzed in NSCLC cells by Kim et al. Western analyses demonstrated stimulation of the NFKB pathway by tocilizumab. Their data suggest that tocilizumab has a potent anticancer effectiveness through apoptosis induction, proposing that this anti-IL-6R antibody may be employed as a novel targeting molecule for NSCLC treatment [57].

\section{Leptin}

Leptin is an imperative pro-inflammatory cytokine mainly produced by white adipose tissue and implicated in pathophysiological mechanisms associated with diabetes and its complications [58]. Leptin levels are elevated in overweight or obese people [59]. A study examining the link between plasma leptin levels and diabetes mellitus demonstrate that higher plasma leptin concentrations are associated with diabetes mellitus but not independently associated with diabetes mellitus after adjustment for body mass index (BMI) [60]. Leptin can adjust energy homeostasis through modulating food intake and energy expenditure via its effect on the hypothalamus; alternatively, it also induces cell growth, migration, and invasion [61]. Thus, leptin may play an important etiologic role in triggering malignant transformation or tumor development. For instance, preclinical evidence has revealed 
that leptin stimulates esophageal, colorectal, prostate and breast cancer cell proliferation [62-66] and is responsible for the association between diabetes and prostate cancer [67]. The leptin-receptor might predict poor prognosis in patient with advanced gastric cancer (AGC) [68]. In addition, a pooled analysis from three cohorts by StolzenbergSolomon et al. supports an relationship between enhancing leptin levels and pancreatic cancer [69]. The role of leptin in promoting cancer development has also been substantiated by in vivo studies. Actually, leptin-deficient and -resistant mice (ob/ob and db/db mice) do not develop transgene-triggered mammary cancers [70,71].

The mechanisms underlying leptin-related cancer development have been extensive studied. Leptin enhances the synthesis and release of cytokines by macrophages and proangiogenic factors, including fibroblast growth factor 2 (FGF2), vascular endothelial growth factor (VEGF), and matrix metalloproteases 2 and 9 (MMP-2/9) [72], which can prompt neoangiogenesis or further promote cancer cells [73]. Leptin has also been shown to significantly augment endothelial cell (EC) growth via a BCL2-dependent mechanism [74-77]. Leptin can elevate estrogen synthesis via activation of aromatase, thus promoting cancer growth in breast and endometrial cancer [78]. Recently, Chang et al. demonstrate that leptin stimulates STAT3 and G9a histone methyltransferase to silence miR-200c, a genetic program of epithelial homeostasis in breast cancer stem-like cells (CSC) that induces malignant development [79]. In addition, leptin is able to activate STAT3 in colitis-associated colon cancer (CAC) cells [80-84]. A recent study suggest that leptin can induce EMT in BC cells and this involves IL-8 activation via the PI3K/Akt signaling pathway [85].

\section{Plasminogen activator inhibitor-1 (PAI-1)}

Extracellular proteases regulate various physiological and pathological processes, e.g. organ development, inflammation, tissue injury/repair, and cancer [86,87]. The urokinase plasminogen activator (uPA)-plasmin is one of the most explored protease systems [88-90]. The serine protease uPA is activated when binding to its receptor uPAR on the cell surface [91]. The proteolytic activity of uPA is explicitly regulated by plasminogen activator inhibitor-1 (PAI-1), a glycoprotein of roughly $50 \mathrm{kDa}$, which upon combining with uPA facilitates the swift endocytosis of the trimolecular uPA/PAI-1/uPAR complex $[92,93]$. PAI-1 is synthesized by vasculature-surrounding cells such as endothelial cells and platelets. Its circulating active form is comparatively unstable. Nevertheless, PAI-1 is stabilized by vitronectin $(\mathrm{VN})$ in blood circulation and extracellular matrix. This abundant glycoprotein is involved in thromboembolic diseases, atherosclerosis, fibrosis, cell migration, cell invasion, cell proliferation, cancer, and tissue remodeling [94]. PAI-1 expression can be regulated by multiple factors, such as TGF- $\beta 1$ [95], inflammatory factors [96], lipids [97-100], glucose and insulin [101-103], p53 and the cell cycle [104-106, phorbol ester $[107,108]$, hypoxia $[109,110]$ and cell adhesion [111-114].

In the last two decades, increasing evidence suggest that an elevated level of PAI-1 protein in human primary tumors represents one of the most helpful biochemical markers of an unfavorable prognosis in a number of human cancer types. This observation has given the motivation to substantial research on the role of PAI-1 in cancer growth, invasion, and metastasis [115]. Recently, Buta et al. propose that tumor size and PAI-1 can be used in combination as prognostic and predictive phenotypes in node-negative, postmenopausal $\mathrm{BC}$ patients bearing histological grade II tumors with ER/PR expression [116]. Positive stroma PAI-1 protein expression in the human epidermal growth factor receptor 2 (HER2)-negative patients is related to lower risk of death, hence it might identify a subgroup of HER2negative advanced BC patients who may benefit from trastuzumab treatment [117] and can be securely spared the toxicity and expenses of adjuvant chemotherapy [118]. Both PAI-1 and UPA stimulate cancer development and metastasis. Increased UPA and PAI-1 in BC tissue are independent and effective predictors of unfavorable outcome of $\mathrm{BC}$ patients, including patients with lymph node-negative disease. Apart from being prognostic biomarkers, overexpression of uPA and PAI-1 is capable of predicting benefit from adjuvant chemotherapy in early BC patients [118]. In addition, Suh et al. demonstrated that upregulation of PAI-1 is associated with aggressive lymph node metastasis in AGC [119].

The first evidence illuminating the link of PAI-1 to more aggressive cancers came from the observation that PAI-1 possesses a proangiogenic property via its anti-protease and vitronectin-binding functions facilitating the detachment of endothelial cells from vitronectin and their movement to fibronectin rich tissues [120,121]. Nonetheless, this angiogenesis activity is dose-dependent with a stimulatory activity at physiologic levels $[120,122]$ and a suppressive activity at pharmacologic levels [123]. PAI-1 hinders spontaneous apoptosis in tumor cells via various mechanisms. It suppresses Fas/Fas-L-mediated apoptosis in a number of human cancer cells via regulating pericellular plasmin activity [124,125]. Moreover, extracellular PAI-1 affects intrinsic (mitochondria-dependent) apoptosis through inhibiting the initiator caspase-9 in cancer cells [126]. Intracellular PAI-1 supports cell survival and protects cancer cells from chemotherapy-triggered apoptosis via suppressing caspase-3 [127].

Since PAI-1 expression is increased in a number of cancer types, it has been anticipated to be a possible target for cancer treatment. However, the role of PAI-1 in tumorgenesis still remains controversial. PAI-1 at physiological level might promote angiogenesis and cancer growth [123,128-132]. Angiogenesis and cancer do not develop under PAI-1-deficient condition [129,133]. Nevertheless, substantial studies suggest that PAI-1 at pharmacological levels hinders cancer growth and angiogenesis $[123,128,130,131,134-137]$. The suppression of PAI-1 by Tiplaxtinin (PAI-039), a specific inhibitor of PAI-1, or siRNA can inhibit tumor-initiating cells within head and neck cancer cell lines via downregulating the sex-determining region Y-box 2 (Sox2) [138]. Some studies reveal that antibodies against PAI-1 may inhibit human cancer cell metastasis in mouse xenograft models [139-141]. Furthermore, the researchers have screened a number of small molecule PAI- 1 inhibitors [142-144], trying to develop some novel cancer therapeutic agents.

\section{Resistin}

Resistin, a signaling molecule secreted by adipocytes and monocytes, belongs to cysteine-rich protein family named "resistinlike molecules" [145,146]. It is up-regulated in obesity and participates in the pathogenesis of insulin resistance [146,147], type 2 diabetes [148-150] and metabolic syndrome (MS) [151]. Accumulating evidence shows that resistin plays an imperative controlling role in inflammatory disease [152,153]. Resistin expression at mRNA level is significantly augmented by pro-inflammatory cytokines $[154,155]$. Clinically, resistin concentrations are related to inflammatory markers obviously independent of BMI and can be used as a predictive factor for coronary atherosclerosis $[152,156,157]$.

Sun et al. [158] and Dalamaga et al. [159] demonstrate that patients with breast cancer (BC) have strikingly enhanced resistin levels when compared with control subjects and patients with benign breast lesions (BBL). Additionally, the biological gradient of $\mathrm{BC}$ risk by plasma 
resistin concentrations still exists following adjustment for measurers of adiposity. The dose-dependent relationship between resistin levels and $\mathrm{BC}$ risk is remarkably prominent in female with superfluous exposure to estrogens. Thus, resistin might have an adiposity-independent role in $\mathrm{BC}$ pathogenesis. High resistin levels in BC tissue are related to a more malignant pathological status and unfavorable patient survival [160]. Thus, resistin might be potentially employed as a prognosis predictor for $\mathrm{BC}$, a marker for hormone treatment stratification, as well as a possible therapeutic target. Moreover, resistin has been discovered to associate with other cancer types such as prostatic, colorectal, gastroesophageal and endometrial cancer [161-168]. In cancer patients, resistin is dramatically related to tumor markers, cancer stage, tumor size, grade and lymph node invasion $[159,169]$.

Resistin's effects on cancer progression involve multiple mechanisms. Deshmukh et al. substantiate that resistin stimulates growth and aggressiveness of $\mathrm{BC}$ cells, and these effects are mediated by STAT3 activation [170]. In addition, resistin advances chondrosarcoma metastasis and expression of MMP-2 via activating the AMP-activated protein kinase (AMPK)/p38 mitogen-activated protein kinase (MAPK) pathway and downregulating miR-519d expression. Hence, resistin might represent a latent new therapeutic target in chondrosarcoma metastasis [171]. Hsieh YY et al. demonstrate that resistin promotes stromal cell-derived factor-1 (SDF-1) expression by Toll-like receptor 4 (TLR4) and stimulation of $\mathrm{p} 38 \mathrm{MAPK} / \mathrm{NFkB}$ pathway in gastric cancer cells, which could explain a novel role of resistin in the association between obesity and gastric cancer [172].

In addition to aforementioned diabetes-associated dysregulated cytokines, other diabetes-related cytokines involved in cancer initiation and progression include C-X-C chemokine ligand 16 (CXCL16) [173183], IL-1 [184-187], IL-10 [188-192], IL-12 [193-195], IL-18 [196198], macrophage migration inhibitory factor (MIF) [199-202], and hepatocyte growth factor (HGF) [203-207].

\section{Concluding comments}

Diabetes, especially T2DM, and diabetes risk factors might be related to cancer. Robust and conceivable evidence propose associations between diabetes and cancer; nonetheless, the underlying mechanisms are poorly understood and there is little applicable clinical management of patients presenting with these diseases concomitantly. Accordingly, a multidisciplinary method is required to reveal the mechanisms underlying the links between diabetes and cancer, eventually improve clinical outcomes.

Currently, increasing attention has been given to the role of cytokine in cancer initiation and progression. Diabetes-associated cytokine dysregulation may be an important pathogenesis responsible for diabetes-related cancer. The important role of cytokines has been described, as a diagnostic or prognostic marker for tumor. For instance, the measurement of the serum concentrations of cytokines, e.g. resistin, IL-6 and IL-10, may have guiding significance for tumorigenic process or prognosis $[40,208]$. While various cytokines prompt carcinogenesis, their pro-tumoral roles rely on the equilibrium of distinct inflammatory mediators and the stage of cancer development. Therefore, investigating the roles of these mediators in various cancers or stages of development is indispensable for designing novel personalized managements by means of these latent therapeutic targets.

Although advancement has been made in the comprehension of the mechanisms of diabetes-associated dysregulated cytokines in tumorigenesis and cancer development, establishing a correlation between cytokines regulation and disease progression, as well as response to treatment still remains a challenge.

\section{Authors' contributions}

YW and YL contributed to the conception of the idea, literature search and writing the manuscript. YD and JV contributed to the critical evaluation and editing of the manuscript. All authors critically reviewed and accepted the final version of the manuscript.

\section{Acknowledgements}

This work was supported by the National Institutes of Health (NIH, NCI, NIMHD, NCATS) Grants: U54 CA143931-01, U54MD007598, UL1TR000124 (J.V. Vadgama) and NIH/NCI grant SC1CA200517 (Y.Wu). All authors critically reviewed the manuscript, including editing of draft, and approved the final version for submission. The authors would like to acknowledge the Accelerating Excellence In Translational Science (AXIS) professional development and pilot project core director for his critical review of the manuscript.

\section{References}

1. Lopez AD, Mathers CD, Ezzati M, Jamison DT, Murray CJ (2006) Global and regional burden of disease and risk factors, 2001: systematic analysis of population health data. Lancet 367: 1747-1757. [Crossref]

2. Cohen DH, LeRoith D (2012) Obesity, type 2 diabetes, and cancer: the insulin and IGF connection. Endocr Relat Cancer 19: F27-45. [Crossref]

3. Giovannucci E, Harlan DM, Archer MC, Bergenstal RM, Gapstur SM, et al. (2010) Diabetes and cancer: a consensus report. Diabetes Care 33: 1674-1685. [Crossref]

4. Vigneri P, Frasca F, Sciacca L, Pandini G, Vigneri R (2009) Diabetes and cancer Endocr Relat Cancer 16: 1103-1123. [Crossref]

5. Jalving M, Gietema JA, Lefrandt JD, de Jong S, Reyners AK, et al. (2010) Metformin taking away the candy for cancer? Eur J Cancer 46: 2369-2380. [Crossref]

6. Johnson JA, Pollak M (2010) Insulin, glucose and the increased risk of cancer in patients with type 2 diabetes. Diabetologia 53: 2086-2088. [Crossref]

7. Pitocco D, Tesauro M, Alessandro R, Ghirlanda G, Cardillo C (2013) Oxidative stress in diabetes: implications for vascular and other complications. Int J Mol Sci 14: 21525 21550. [Crossref]

8. Lee SC, Chan JC (2015) Evidence for DNA damage as a biological link between diabetes and cancer. Chin Med J (Engl) 128: 1543-1548. [Crossref]

9. Currie CJ, Poole CD, Gale EA (2009) The influence of glucose-lowering therapies on cancer risk in type 2 diabetes. Diabetologia 52: 1766-1777. [Crossref]

10. Jonasson JM, Ljung R, Talbäck M, Haglund B, Gudbjörnsdòttir S, et al. (2009) Insulin glargine use and short-term incidence of malignancies-a population-based follow-up study in Sweden. Diabetologia 52: 1745-1754. [Crossref]

11. Shukla A, Grisouard J, Ehemann V, Hermani A, Enzmann H, et al. (2009) Analysis of signaling pathways related to cell proliferation stimulated by insulin analogs in human mammary epithelial cell lines. Endocr Relat Cancer 16: 429-441. [Crossref]

12. Kurtzhals P, Schäffer L, Sørensen A, Kristensen C, Jonassen I, et al. (2000) Correlations of receptor binding and metabolic and mitogenic potencies of insulin analogs designed for clinical use. Diabetes 49: 999-1005. [Crossref]

13. Liefvendahl E, Arnqvist HJ (2008) Mitogenic effect of the insulin analogue glargine in malignant cells in comparison with insulin and IGF-I. Horm Metab Res 40: 369-374. [Crossref]

14. Mink PJ, Shahar E, Rosamond WD, Alberg AJ, Folsom AR (2002) Serum insulin and glucose levels and breast cancer incidence: the atherosclerosis risk in communities study. Am J Epidemiol 156: 349-352. [Crossref]

15. Kabat GC, Kim MY, Strickler HD, Shikany JM, Lane D, et al. (2012) A longitudina study of serum insulin and glucose levels in relation to colorectal cancer risk among postmenopausal women. Br J Cancer 106: 227-232. [Crossref]

16. Landskron G, De la Fuente M, Thuwajit P, Thuwajit C, Hermoso MA (2014) Chronic inflammation and cytokines in the tumor microenvironment. J Immunol Res 2014 149185. [Crossref] 
17. Esposito K, Nappo F, Marfella R, Giugliano G, Giugliano F, et al. (2002) Inflammatory cytokine concentrations are acutely increased by hyperglycemia in humans: role of oxidative stress. Circulation 106: 2067-2072. [Crossref]

18. Costantini S, Capone F, Guerriero E, Marfella R, Sorice A, et al. (2012) Cytokinome profile of patients with type 2 diabetes and/or chronic hepatitis $\mathrm{C}$ infection. PLoS One 7: e39486. [Crossref]

19. Moore RJ, Owens DM, Stamp G, Arnott C, Burke F, et al. (1999) Mice deficient in tumor necrosis factor-alpha are resistant to skin carcinogenesis. Nat Med 5: 828-831. [Crossref]

20. Balkwill F (2002) Tumor necrosis factor or tumor promoting factor? Cytokine Growth Factor Rev 13: 135-141. [Crossref]

21. Balkwill F (2009) Tumour necrosis factor and cancer. Nat Rev Cancer 9: 361-371. [Crossref]

22. Bromberg JF, Wrzeszczynska MH, Devgan G, Zhao Y, Pestell RG, et al. (1999) Stat3 as an oncogene. Cell 98: 295-303. [Crossref]

23. Pickup JC, Mattock MB, Chusney GD, Burt D (1997) NIDDM as a disease of the innate immune system: association of acute-phase reactants and interleukin-6 with metabolic syndrome X. Diabetologia 40: 1286-1292. [Crossref]

24. Pickup JC, Chusney GD, Thomas SM, Burt D (2000) Plasma interleukin-6, tumour necrosis factor alpha and blood cytokine production in type 2 diabetes. Life Sci 67: 291-300. [Crossref]

25. Arnalich F, Hernanz A, López-Maderuelo D, Peña JM, Camacho J, et al. (2000) Enhanced acute-phase response and oxidative stress in older adults with type II diabetes. Horm Metab Res 32: 407-412. [Crossref]

26. Kado S, Nagase T, Nagata N (1999) Circulating levels of interleukin-6, its soluble receptor and interleukin-6/interleukin-6 receptor complexes in patients with type 2 diabetes mellitus. Acta Diabetol 36: 67-72. [Crossref]

27. Shikano M, Sobajima H, Yoshikawa H, Toba T, Kushimoto H, et al. (2000) Usefulness of a highly sensitive urinary and serum IL-6 assay in patients with diabetic nephropathy. Nephron 85: 81-85. [Crossref]

28. Popa C, Netea MG, van Riel PL, van der Meer JW, Stalenhoef AF (2007) The role of TNF-alpha in chronic inflammatory conditions, intermediary metabolism, and cardiovascular risk. J Lipid Res 48: 751-762. [Crossref]

29. Balkwill F (2006) TNF-alpha in promotion and progression of cancer. Cancer Metastasis Rev 25: 409-416. [Crossref]

30. Szlosarek P, Charles KA, Balkwill FR (2006) Tumour necrosis factor-alpha as a tumour promoter. Eur J Cancer 42: 745-750. [Crossref]

31. Woo CH, Eom YW, Yoo MH, You HJ, Han HJ, et al. (2000) Tumor necrosis factoralpha generates reactive oxygen species via a cytosolic phospholipase A2-linked cascade. J Biol Chem 275: 32357-32362. [Crossref]

32. Kwong J, Chan FL, Wong KK, Birrer MJ, Archibald KM, et al. (2009) Inflammatory cytokine tumor necrosis factor alpha confers precancerous phenotype in an organoid model of normal human ovarian surface epithelial cells. Neoplasia 11: 529-541. [Crossref]

33. Lee SH, Hong HS, Liu ZX, Kim RH, Kang MK, et al. (2012) TNF $\alpha$ enhances cancer stem cell-like phenotype via Notch-Hes1 activation in oral squamous cell carcinoma cells. Biochem Biophys Res Commun 424: 58-64. [Crossref]

34. Gallagher EJ, LeRoith D1 (2015) Obesity and Diabetes: The Increased Risk of Cancer and Cancer-Related Mortality. Physiol Rev 95: 727-748. [Crossref]

35. Matsunaga T, Misaka T, Hosokawa K, Taira S, Kim K, et al. (2009) Intraductal approach to the detection of intraductal lesions of the breast. Breast Cancer Res Treat 118: 9-13. [Crossref]

36. Hsu EC, Kulp SK, Huang HL, Tu HJ, Salunke SB, et al. (2015) Function of IntegrinLinked Kinase in Modulating the Stemness of IL-6-Abundant Breast Cancer Cells by Regulating gamma-Secretase-Mediated Notch1 Activation in Caveolae. Neoplasia 17: 497-508. [Crossref]

37. Becker C, Fantini MC, Wirtz S, Nikolaev A, Lehr HA, et al. (2005) IL-6 signaling promotes tumor growth in colorectal cancer. Cell Cycle 4: 217-220. [Crossref]

38. Knüpfer H, Preiss R (2007) Significance of interleukin-6 (IL-6) in breast cancer (review). Breast Cancer Res Treat 102: 129-135. [Crossref]

39. Lin WW, Karin M (2007) A cytokine-mediated link between innate immunity, inflammation, and cancer. J Clin Invest 117: 1175-1183. [Crossref]
40. Heikkilä K, Ebrahim S, Lawlor DA (2008) Systematic review of the association between circulating interleukin-6 (IL-6) and cancer. Eur J Cancer 44: 937-945. [Crossref]

41. Chaftari AM, Hachem R, Reitzel R, Jordan M, Jiang Y, et al. (2015) Role of Procalcitonin and Interleukin-6 in Predicting Cancer, and Its Progression Independent of Infection. PLoS One 10: e0130999. [Crossref]

42. Grivennikov S, Karin M (2008) Autocrine IL-6 signaling: a key event in tumorigenesis? Cancer Cell 13: 7-9. [Crossref]

43. Waldner MJ, Neurath MF (2008) Cytokines in colitis associated cancer: potential drug targets? Inflamm Allergy Drug Targets 7: 187-194. [Crossref]

44. Naugler WE, Karin M (2008) The wolf in sheep's clothing: the role of interleukin-6 in immunity, inflammation and cancer. Trends Mol Med 14: 109-119. [Crossref]

45. Grivennikov S, Karin E, Terzic J, Mucida D, Yu GY, et al. (2009) IL-6 and Stat3 are required for survival of intestinal epithelial cells and development of colitis-associated cancer. Cancer cell 15: 103-113. [Crossref]

46. Matsumoto S, Hara T, Mitsuyama K, Yamamoto M, Tsuruta O, et al. (2010) Essential roles of IL-6 trans-signaling in colonic epithelial cells, induced by the IL-6/solubleIL-6 receptor derived from lamina propria macrophages, on the development of colitis-associated premalignant cancer in a murine model. J Immunol 184: 1543-1551. [Crossref]

47. Hodge DR, Hurt EM, Farrar WL (2005) The role of IL-6 and STAT3 in inflammation and cancer. Eur J Cancer 41: 2502-2512. [Crossref]

48. Chatterjee M, Stühmer T, Herrmann P, Bommert K, Dörken B, et al. (2004) Combined disruption of both the MEK/ERK and the IL-6R/STAT3 pathways is required to induce apoptosis of multiple myeloma cells in the presence of bone marrow stromal cells Blood 104: 3712-3721. [Crossref]

49. Hilbert DM, Kopf M, Mock BA, Köhler G, Rudikoff S (1995) Interleukin 6 is essentia for in vivo development of B lineage neoplasms. J Exp Med 182: 243-248. [Crossref]

50. Gasche JA, Hoffmann J, Boland CR, Goel A (2011) Interleukin-6 promotes tumorigenesis by altering DNA methylation in oral cancer cells. Int J Cancer 129 : 1053-1063. [Crossref]

51. Kim SY, Kang JW, Song X, Kim BK, Yoo YD, et al. (2013) Role of the IL-6-JAK1STAT3-Oct-4 pathway in the conversion of non-stem cancer cells into cancer stem-like cells. Cell Signal 25: 961-969. [Crossref]

52. Song L, Rawal B, Nemeth JA, Haura EB (2011) JAK1 activates STAT3 activity in nonsmall-cell lung cancer cells and IL-6 neutralizing antibodies can suppress JAK1-STAT3 signaling. Mol Cancer Ther 10: 481-494. [Crossref]

53. Coward J, Kulbe H, Chakravarty P, Leader D, Vassileva V, et al. (2011) Interleukin-6 as a therapeutic target in human ovarian cancer. Clin Cancer Res 17: 6083-6096. [Crossref]

54. Kurzrock R, Voorhees PM, Casper C, Furman RR, Fayad L, et al. (2013) A phase I, open-label study of siltuximab, an anti-IL-6 monoclonal antibody, in patients with B-cell non-Hodgkin lymphoma, multiple myeloma, or Castleman disease. Clin Cancer Res 19: 3659-3670. [Crossref]

55. Rossi JF, Négrier S, James ND, Kocak I, Hawkins R, et al. (2010) A phase I/II study of siltuximab (CNTO 328), an anti-interleukin-6 monoclonal antibody, in metastatic renal cell cancer. Br J Cancer 103: 1154-1162. [Crossref]

56. Dorff TB, Goldman B, Pinski JK, Mack PC, Lara PN Jr, et al. (2010) Clinical and correlative results of SWOG S0354: a phase II trial of CNTO328 (siltuximab), a monoclonal antibody against interleukin-6, in chemotherapy-pretreated patients with castration-resistant prostate cancer. Clin Cancer Res 16: 3028-3034. [Crossref]

57. Kim NH, Kim SK, Kim DS, Zhang D, Park JA, et al. (2015) Anti-proliferative action of IL-6R-targeted antibody tocilizumab for non-small cell lung cancer cells. Oncol Lett 9: 2283-2288. [Crossref]

58. Maffei M, Fei H, Lee GH, Dani C, Leroy P, et al. (1995) Increased expression in adipocytes of ob RNA in mice with lesions of the hypothalamus and with mutations at the db locus. Proc Natl Acad Sci U S A 92: 6957-6960. [Crossref]

59. Paz-Filho G, Lim EL, Wong ML, Licinio J (2011) Associations between adipokines and obesity-related cancer. Front Biosci (Landmark Ed) 16: 1634-1650. [Crossref]

60. Bandaru P, Shankar A (2011) Association between plasma leptin levels and diabetes mellitus. Metab Syndr Relat Disord 9: 19-23. [Crossref]

61. Garofalo C, Surmacz E (2006) Leptin and cancer. J Cell Physiol 207: 12-22. [Crossref]

62. Hu X, Juneja SC, Maihle NJ, Cleary MP (2002) Leptin--a growth factor in normal and 
malignant breast cells and for normal mammary gland development. J Natl Cancer Inst 94: 1704-1711. [Crossref]

63. Dieudonne MN, Machinal-Quelin F, Serazin-Leroy V, Leneveu MC, Pecquery R, et al. (2002) Leptin mediates a proliferative response in human MCF7 breast cancer cells. Biochem Biophys Res Commun 293: 622-628. [Crossref]

64. Onuma M, Bub JD, Rummel TL, Iwamoto Y (2003) Prostate cancer cell-adipocyte interaction: leptin mediates androgen-independent prostate cancer cell proliferation through c-Jun NH2-terminal kinase. J Biol Chem 278: 42660-42667. [Crossref]

65. Somasundar P, Frankenberry KA, Skinner H, Vedula G, McFadden DW, et al. (2004) Prostate cancer cell proliferation is influenced by leptin. J Surg Res 118: 71-82. [Crossref]

66. Endo H, Hosono K, Uchiyama T, Sakai E, Sugiyama M, et al. (2011) Leptin acts as a growth factor for colorectal tumours at stages subsequent to tumour initiation in murine colon carcinogenesis. Gut 60: 1363-1371. [Crossref]

67. Kasper JS, Giovannucci E (2006) A meta-analysis of diabetes mellitus and the risk of prostate cancer. Cancer Epidemiol Biomarkers Prev 15: 2056-2062. [Crossref]

68. Choi E, Byeon SJ, Kim SH, Lee HJ, Kwon HJ, et al. (2015) Implication of LeptinSignaling Proteins and Epstein-Barr Virus in Gastric Carcinomas. PLoS One 10: e0130839. [Crossref]

69. Stolzenberg-Solomon RZ, Newton CC, Silverman DT, Pollak M, Nogueira LM, et al (2015) Circulating Leptin and Risk of Pancreatic Cancer: A Pooled Analysis From 3 Cohorts. Am J Epidemiol 182: 187-197. [Crossref]

70. Cleary MP, Phillips FC, Getzin SC, Jacobson TL, Jacobson MK, et al. (2003) Genetically obese MMTV-TGF-alpha/Lep(ob)Lep(ob) female mice do not develop mammary tumors. Breast Cancer Res Treat 77: 205-215. [Crossref]

71. Cleary MP, Grande JP, Juneja SC, Maihle NJ (2004) Diet-induced obesity and mammary tumor development in MMTV-neu female mice. Nutr Cancer 50: 174-180. [Crossref]

72. Park HY, Kwon HM, Lim HJ, Hong BK, Lee JY, et al. (2001) Potential role of leptin in angiogenesis: leptin induces endothelial cell proliferation and expression of matrix metalloproteinases in vivo and in vitro. Exp Mol Med 33: 95-102. [Crossref]

73. Trayhurn P, Wood IS (2004) Adipokines: inflammation and the pleiotropic role of white adipose tissue. Br J Nutr 92: 347-355. [Crossref]

74. Bouloumié A, Drexler HC, Lafontan M, Busse R (1998) Leptin, the product of $\mathrm{Ob}$ gene, promotes angiogenesis. Circ Res 83: 1059-1066. [Crossref]

75. Sierra-Honigmann MR, Nath AK, Murakami C, García-Cardeña G, Papapetropoulos A, et al. (1998) Biological action of leptin as an angiogenic factor. Science 281: 16831686. [Crossref]

76. Cao R, Brakenhielm E, Wahlestedt C, Thyberg J, Cao Y (2001) Leptin induces vascular permeability and synergistically stimulates angiogenesis with FGF-2 and VEGF. Proc Natl Acad Sci U S A 98: 6390-6395. [Crossref]

77. Artwohl M, Roden M, Holzenbein T, Freudenthaler A, Waldhausl W, et al. (2002) Modulation by leptin of proliferation and apoptosis in vascular endothelial cells. Int $J$ Obes Relat Metab Disord 26: 577-580. [Crossref]

78. Boden G, Chen X, Mozzoli M, Ryan I (1996) Effect of fasting on serum leptin in normal human subjects. J Clin Endocrinol Metab 81: 3419-3423. [Crossref]

79. Chang CC, Wu MJ, Yang JY, Camarillo IG, Chang CJ (2015) Leptin-STAT3-G9a Signaling Promotes Obesity-Mediated Breast Cancer Progression. Cancer Res 75: 2375-2386. [Crossref]

80. Bollrath J, Phesse TJ, von Burstin VA, Putoczki T, Bennecke M, et al. (2009) gp130-mediated Stat3 activation in enterocytes regulates cell survival and cell-cycle progression during colitis-associated tumorigenesis. Cancer Cell 15: 91-102. [Crossref]

81. Ernst M, Najdovska M, Grail D, Lundgren-May T, Buchert M, et al. (2008) STAT3 and STAT1 mediate IL-11-dependent and inflammation-associated gastric tumorigenesis in gp130 receptor mutant mice. J Clin Invest 118: 1727-1738. [Crossref]

82. Pickert G, Neufert C, Leppkes M, Zheng Y, Wittkopf N, et al. (2009) STAT3 links IL22 signaling in intestinal epithelial cells to mucosal wound healing. J Exp Med 206: 1465-1472. [Crossref]

83. Jarnicki A, Putoczki T, Ernst M (2010) Stat3: linking inflammation to epithelial cancer - more than a "gut" feeling? Cell Div 5: 14. [Crossref]

84. Chalaris A, Adam N, Sina C, Rosenstiel P, Lehmann-Koch J, et al. (2010) Critical role of the disintegrin metalloprotease ADAM17 for intestinal inflammation and regeneration in mice. $J$ Exp Med 207: 1617-1624. [Crossref]
85. Wang L, Tang C, Cao H, Li K, Pang X, et al. (2015) Activation of IL-8 via PI3K/Aktdependent pathway is involved in leptin-mediated epithelial-mesenchymal transition in human breast cancer cells. Cancer Biol Ther 16: 1220-1230. [Crossref]

86. Werb Z (1997) ECM and cell surface proteolysis: regulating cellular ecology. Cell 91: 439-442. [Crossref]

87. Page-McCaw A, Ewald AJ, Werb Z (2007) Matrix metalloproteinases and the regulation of tissue remodelling. Nat Rev Mol Cell Biol 8: 221-233. [Crossref]

88. Blasi F, Sidenius N (2010) The urokinase receptor: focused cell surface proteolysis, cell adhesion and signaling. FEBS Lett 584: 1923-1930. [Crossref]

89. Dass K, Ahmad A, Azmi AS, Sarkar SH, Sarkar FH (2008) Evolving role of uPA/uPAR system in human cancers. Cancer Treat Rev 34: 122-136. [Crossref]

90. McMahon B, Kwaan HC (2008) The plasminogen activator system and cancer Pathophysiol Haemost Thromb 36: 184-194. [Crossref]

91. Blasi F, Verde P (1990) Urokinase-dependent cell surface proteolysis and cancer. Semin Cancer Biol 1: 117-126. [Crossref]

92. Dupont DM, Madsen JB, Kristensen T, Bodker JS, Blouse GE, et al. (2009) Biochemical properties of plasminogen activator inhibitor-1. Front Biosci (Landmark Ed) 14: 1337 1361. [Crossref]

93. Cale JM, Lawrence DA (2007) Structure-function relationships of plasminogen activator inhibitor-1 and its potential as a therapeutic agent. Curr Drug Targets 8: 971981. [Crossref]

94. Rouch A, Vanucci-Bacque C, Bedos-Belval F, Baltas M (2015) Small molecules inhibitors of plasminogen activator inhibitor-1 - an overview. Eur J Med Chem 92: 619-636. [Crossref]

95. Dennler S, Itoh S, Vivien D, ten Dijke P, Huet S, et al. (1998) Direct binding of Smad3 and Smad4 to critical TGF beta-inducible elements in the promoter of human plasminogen activator inhibitor-type 1 gene. EMBO J 17: 3091-3100. [Crossref]

96. Zhang WJ, Wojta J, Binder BR (1997) Notoginsenoside R1 counteracts endotoxininduced activation of endothelial cells in vitro and endotoxin-induced lethality in mice in vivo. Arterioscler Thromb Vasc Biol 17: 465-474. [Crossref]

97. Chen Y, Billadello JJ, Schneider DJ (2000) Identification and localization of a fatty acid response region in the human plasminogen activator inhibitor-1 gene. Arterioscler Thromb Vasc Biol 20: 2696-2701. [Crossref]

98. Eriksson P, Nilsson L, Karpe F, Hamsten A (1998) Very-low-density lipoprotein response element in the promoter region of the human plasminogen activator inhibitor-1 gene implicated in the impaired fibrinolysis of hypertriglyceridemia. Arterioscler Thromb Vas Bio 18: 20-26. [Crossref]

99. Panahloo A, Mohamed-Ali V, Lane A, Green F, Humphries SE, et al. (1995) Determinants of plasminogen activator inhibitor 1 activity in treated NIDDM and its relation to a polymorphism in the plasminogen activator inhibitor 1 gene. Diabetes 44 37-42. [Crossref]

100. Mansfield MW, Stickland MH, Grant PJ (1995) Plasminogen activator inhibitor-1 (PAI-1) promoter polymorphism and coronary artery disease in non-insulin-dependent diabetes. Thromb Haemost 74: 1032-1034. [Crossref]

101. Nordt TK, Klassen KJ, Schneider DJ, Sobel BE (1993) Augmentation of synthesis of plasminogen activator inhibitor type-1 in arterial endothelial cells by glucose and its implications for local fibrinolysis. Arterioscler Thromb 13: 1822-1828. [Crossref]

102. Kooistra T, Bosma PJ, Töns HA, van den Berg AP, Meyer P, et al. (1989) Plasminogen activator inhibitor 1: biosynthesis and mRNA level are increased by insulin in cultured human hepatocytes. Thromb Haemost 62: 723-728. [Crossref]

103. Rikitake Y, Liao JK (2005) Rho-kinase mediates hyperglycemia-induced plasminogen activator inhibitor-1 expression in vascular endothelial cells. Circulation 111: 32613268. [Crossref]

104. Kunz C, Pebler S, Otte J, von der Ahe D (1995) Differential regulation of plasminogen activator and inhibitor gene transcription by the tumor suppressor p53. Nucleic Acids Res 23: 3710-3717. [Crossref]

105. Ryan MP, Higgins PJ (1993) Growth state-regulated expression of p52(PAI-1) in normal rat kidney cells. J Cell Physiol 155: 376-384. [Crossref]

106. Mu XC, Staiano-Coico L, Higgins PJ (1998) Increased transcription and modified growth state-dependent expression of the plasminogen activator inhibitor type-1 gene characterize the senescent phenotype in human diploid fibroblasts. J Cell Physiol 174: 90-98. [Crossref]

107. Mayer M, Lund LR, Riccio A, Skouv J, Nielsen LS, et al. (1988) Plasminogen activator 
inhibitor type-1 protein, mRNA and gene transcription are increased by phorbol esters in human rhabdomyosarcoma cells. J Biol Chem 263: 15688-15693. [Crossref]

108. Bosma PJ, Kooistra T (1991) Different induction of two plasminogen activator inhibitor $1 \mathrm{mRNA}$ species by phorbol ester in human hepatoma cells. J Biol Chem 266: 17845-17849. [Crossref]

109. Fink T, Kazlauskas A, Poellinger L, Ebbesen P, Zachar V (2002) Identification of a tightly regulated hypoxia-response element in the promoter of human plasminogen activator inhibitor-1. Blood 99: 2077-2083. [Crossref]

110. Pinsky DJ, Liao H, Lawson CA, Yan SF, Chen J, et al. (1998) Coordinated induction of plasminogen activator inhibitor-1 (PAI-1) and inhibition of plasminogen activator gene expression by hypoxia promotes pulmonary vascular fibrin deposition. $J$ Clin Invest 102: 919-928. [Crossref]

111. Lee CC, Shyu KG, Lin S, Wang BW, Liu YC, et al. (2002) Cell adhesion regulates the plasminogen activator inhibitor-1 gene expression in anchorage-dependent cells Biochem Biophys Res Commun 291: 185-190. [Crossref]

112. Chang H, Shyu KG, Lin S, Wang BW, Liu YC, et al. (2002) Cell adhesion induces the plasminogen activator inhibitor-1 gene expression through phosphatidylinositol 3-kinase/Akt activation in anchorage dependent cells. Cell Commun Adhes 9: 239247. [Crossref]

113. Chang H, Shyu KG, Lin S, Tsai SC, Wang BW, et al. (2003) The plasminogen activator inhibitor-1 gene is induced by cell adhesion through the MEK/ERK pathway. $J$ Biomed Sci 10: 738-745. [Crossref]

114. Hapke S, Kessler H, Arroyo de Prada N, Benge A, Schmitt M, et al. (2001) Integrin alpha(v)beta(3)/vitronectin interaction affects expression of the urokinase system in human ovarian cancer cells. J Biol Chem 276: 26340-26348. [Crossref]

115. Andreasen PA (2007) PAI-1 - a potential therapeutic target in cancer. Curr Drug Targets 8: 1030-1041. [Crossref]

116. Buta M, Dzodic R, Durisic I, Markovic I, Vujasinovic T, et al. (2015) Potential clinical relevance of uPA and PAI-1 levels in node-negative, postmenopausal breast cancer patients bearing histological grade II tumors with ER/PR expression, during an early follow-up. Tumour Biol 36: 8193-8200. [Crossref]

117. Koumarianou A, Karayannopoulou G, Gourgioti G, Batistatou A, Bobos M, et al. (2015) PAI-1 and HER2 interaction in advanced breast cancer disease: evidence for added benefit from trastuzumab in HER2-negative patients. Cancer Chemother Pharmacol 75: 1289-1301. [Crossref]

118. Duffy MJ, McGowan PM, Harbeck N, Thomssen C, Schmitt M (2014) uPA and PAI1 as biomarkers in breast cancer: validated for clinical use in level-of-evidence-1 studies. Breast Cancer Res 16: 428. [Crossref]

119. Suh YS, Yu J, Kim BC, Choi B, Han TS, et al. (2015) Overexpression of Plasminogen Activator Inhibitor-1 in Advanced Gastric Cancer with Aggressive Lymph Node Metastasis. Cancer Res Treat 47: 718-726. [Crossref]

120. Isogai C, Laug WE, Shimada H, Declerck PJ, Stins MF, et al. (2001) Plasminogen activator inhibitor-1 promotes angiogenesis by stimulating endothelial cell migration toward fibronectin. Cancer Res 61: 5587-5594. [Crossref]

121. Placencio VR, DeClerck YA (2015) Plasminogen Activator Inhibitor-1 in Cancer: Rationale and Insight for Future Therapeutic Testing. Cancer Res 75: 2969-2974. [Crossref]

122. Bajou K, Masson V, Gerard RD, Schmitt PM, Albert V, et al. (2001) The plasminogen activator inhibitor PAI-1 controls in vivo tumor vascularization by interaction with proteases, not vitronectin. Implications for antiangiogenic strategies. J Cell Biol 152: 777-784. [Crossref]

123. Bajou K, Maillard C, Jost M, Lijnen RH, Gils A, et al. (2004) Host-derived plasminogen activator inhibitor-1 (PAI-1) concentration is critical for in vivo tumoral angiogenesis and growth. Oncogene 23: 6986-6990. [Crossref]

124. Fang H, Placencio VR, DeClerck YA (2012) Protumorigenic activity of plasminogen activator inhibitor-1 through an antiapoptotic function. J Natl Cancer Inst 104: 14701484. [Crossref]

125. Valiente M, Obenauf AC, Jin X, Chen Q, Zhang XH, et al. (2014) Serpins promote cancer cell survival and vascular co-option in brain metastasis. Cell 156: 1002-1016. [Crossref]

126. Balsara RD, Castellino FJ, Ploplis VA (2006) A novel function of plasminogen activator inhibitor-1 in modulation of the AKT pathway in wild-type and plasminogen activator inhibitor-1-deficient endothelial cells. J Biol Chem 281: 22527-22536. [Crossref]
127. Schneider DJ, Chen Y, Sobel BE (2008) The effect of plasminogen activator inhibitor type 1 on apoptosis. Thromb Haemost 100: 1037-1040. [Crossref]

128. McMahon GA, Petitclerc E, Stefansson S, Smith E, Wong MK, et al. (2001) Plasminogen activator inhibitor-1 regulates tumor growth and angiogenesis. J Biol Chem 276: 33964-33968. [Crossref]

129. Bajou K, Noël A, Gerard RD, Masson V, Brunner N, et al. (1998) Absence of host plasminogen activator inhibitor 1 prevents cancer invasion and vascularization. $\mathrm{Nat}$ Med 4: 923-928. [Crossref]

130. Stefansson S, Petitclerc E, Wong MK, McMahon GA, Brooks PC, et al. (2001) Inhibition of angiogenesis in vivo by plasminogen activator inhibitor-1. $\mathrm{J}$ Biol Chem 276: 8135-8141. [Crossref]

131. Devy L, Blacher S, Grignet-Debrus C, Bajou K, Masson V, et al. (2002) The pro- or antiangiogenic effect of plasminogen activator inhibitor 1 is dose dependent. FASEB $J$ 16: 147-154. [Crossref]

132. Lambert V, Munaut C, Carmeliet P, Gerard RD, Declerck PJ, et al. (2003) Dosedependent modulation of choroidal neovascularization by plasminogen activator inhibitor type I: implications for clinical trials. Inves Ophthalmol Vis Sci 44: 27912797. [Crossref]

133. Gutierrez LS, Schulman A, Brito-Robinson T, Noria F, Ploplis VA, et al. (2000) Tumor development is retarded in mice lacking the gene for urokinase-type plasminogen activator or its inhibitor, plasminogen activator inhibitor-1. Cancer Res 60: 58395847. [Crossref]

134. Praus M, Collen D, Gerard RD (2002) Both u-PA inhibition and vitronectin binding by plasminogen activator inhibitor 1 regulate $\mathrm{HT} 1080$ fibrosarcoma cell metastasis. Int $J$ 102: 584-591. [Crossref]

135. Soff GA, Sanderowitz J, Gately S, Verrusio E, Weiss I, et al. (1995) Expression of plasminogen activator inhibitor type 1 by human prostate carcinoma cells inhibits primary tumor growth, tumor-associated angiogenesis, and metastasis to lung and liver in an athymic mouse model. J Clin Investg 96: 2593-600. [Crossref]

136. Ma D, Gerard RD, Li XY, Alizadeh H, Niederkorn JY (1997) Inhibition of metastasis of intraocular melanomas by adenovirus-mediated gene transfer of plasminogen activator inhibitor type 1 (PAI-1) in an athymic mouse model. Blood 90: 2738-2746. [Crossref]

137. Jankun J, Keck RW, Skrzypczak-Jankun E, Swiercz R (1997) Inhibitors of urokinase reduce size of prostate cancer xenografts in severe combined immunodeficient mice. Cancer Res 57: 559-563. [Crossref]

138. Lee YC, Yu CC, Lan C, Lee CH, Lee HT, et al. (2015) Plasminogen activator inhibitor-1 as regulator of tumor-initiating cell properties in head and neck cancers. Head Neck. [Crossref]

139. Tsuchiya H, Katsuo S, Matsuda E, Sunayama C, Tomita K, et al. (1995) The antibody to plasminogen activator inhibitor-1 suppresses pulmonary metastases of human fibrosarcoma in athymic mice. Gen Diagn Pathol 141: 41-48. [Crossref]

140. Brooks TD, Slomp J, Quax PH, De Bart AC, Spencer MT, et al. (2000) Antibodies to PAI-1 alter the invasive and migratory properties of human tumour cells in vitro. Clin Exp Metastasis 18: 445-453. [Crossref]

141. Ngo TH, Hoylaerts MF, Knockaert I, Brouwers E, Declerck PJ (2001) Identification of a target site in plasminogen activator inhibitor-1 that allows neutralization of its inhibitor properties concomitant with an allosteric up-regulation of its antiadhesive properties. J Biol Chem 276: 26243-26248. [Crossref]

142. Liang A, Wu F, Tran K, Jones SW, Deng G, et al. (2005) Characterization of a small molecule PAI-1 inhibitor, ZK4044. Thromb Res 115: 341-350. [Crossref]

143. Crandall DL, Elokdah H, Di L, Hennan JK, Gorlatova NV, et al. (2004) Characterization and comparative evaluation of a structurally unique PAI-1 inhibitor exhibiting oral invivo efficacy. $J$ Thromb Haemost 2: 1422-1428. [Crossref]

144. Folkes A, Brown SD, Canne LE, Chan J, Engelhardt E, et al. (2002) Design, synthesis and in vitro evaluation of potent, novel, small molecule inhibitors of plasminogen activator inhibitor-1. Bioorg Med Chem Lett 12: 1063-1066. [Crossref]

145. Holcomb IN, Kabakoff RC, Chan B, Baker TW, Gurney A, et al. (2000) FIZZ1, a novel cysteine-rich secreted protein associated with pulmonary inflammation, defines a new gene family. EMBOJ 19: 4046-4055. [Crossref]

146. Steppan CM, Bailey ST, Bhat S, Brown EJ, Banerjee RR, et al. (2001) The hormone resistin links obesity to diabetes. Nature 409: 307-312. [Crossref]

147. Vendrell J, Broch M, Vilarrasa N, Molina A, Gómez JM, et al. (2004) Resistin, 
adiponectin, ghrelin, leptin, and proinflammatory cytokines: relationships in obesity. Obes Res 12: 962-971. [Crossref]

148. Wu H, Yu Z, Qi Q, Li H, Sun Q, et al. (2011) Joint analysis of multiple biomarkers for identifying type 2 diabetes in middle-aged and older Chinese: a cross-sectional study. BMJ Open 1: e000191. [Crossref]

149. Farvid MS, Ng TW, Chan DC, Barrett PH, Watts GF (2005) Association of adiponectin and resistin with adipose tissue compartments, insulin resistance and dyslipidaemia. Diabetes Obes Metab 7: 406-413. [Crossref]

150. Bauer S, Neumeier M, Wanninger J, Walter R, Kopp A, et al. (2011) Systemic resistin is increased in type 2 diabetic patients treated with loop diuretics. $J$ Diabetes Complications 25: 377-381. [Crossref]

151. Malo E, Ukkola O, Jokela M, Moilanen L, Kähönen M, et al. (2011) Resistin is an indicator of the metabolic syndrome according to five different definitions in the Finnish Health 2000 survey. Metab Syndr Relat Disord 9: 203-210. [Crossref]

152. Reilly MP, Lehrke M, Wolfe ML, Rohatgi A, Lazar MA, et al. (2005) Resistin is an inflammatory marker of atherosclerosis in humans. Circulation 111: 932-939. [Crossref]

153. Lehrke M, Reilly MP, Millington SC, Iqbal N, Rader DJ, et al. (2004) An inflammatory cascade leading to hyperresistinemia in humans. PLoS Med 1: e45. [Crossref]

154. Patel L, Buckels AC, Kinghorn IJ, Murdock PR, Holbrook JD, et al. (2003) Resistin is expressed in human macrophages and directly regulated by PPAR gamma activators. Biochem Biophys Res Commun 300: 472-476. [Crossref]

155. Kaser S, Kaser A, Sandhofer A, Ebenbichler CF, Tilg H, et al. (2003) Resistin messenger-RNA expression is increased by proinflammatory cytokines in vitro. Biochem Biophys Res Commun 309: 286-290. [Crossref]

156. Rajala MW, Scherer PE (2003) Minireview: The adipocyte--at the crossroads of energy homeostasis, inflammation, and atherosclerosis. Endocrinology 144: 37653773. [Crossref]

157. Shetty GK, Economides PA, Horton ES, Mantzoros CS, Veves A (2004) Circulating adiponectin and resistin levels in relation to metabolic factors, inflammatory markers, and vascular reactivity in diabetic patients and subjects at risk for diabetes. Diabetes Care 27: 2450-2457. [Crossref]

158. Sun CA, Wu MH, Chu CH, Chou YC, Hsu GC, et al. (2010) Adipocytokine resistin and breast cancer risk. Breast Cancer Res Treat 123: 869-876. [Crossref]

159. Dalamaga M, Sotiropoulos G, Karmaniolas K, Pelekanos N, Papadavid E, et al. (2013) Serum resistin: a biomarker of breast cancer in postmenopausal women? Association with clinicopathological characteristics, tumor markers, inflammatory and metabolic parameters. Clin Biochem 46: 584-590. [Crossref]

160. Lee YC, Chen YJ, Wu CC, Lo S, Hou MF, et al. (2012) Resistin expression in breast cancer tissue as a marker of prognosis and hormone therapy stratification. Gynecol Oncol 125: 742-750. [Crossref]

161. Salageanu A, Tucureanu C, Lerescu L, Caras I, Pitica R, et al. (2010) Serum levels of adipokines resistin and leptin in patients with colon cancer. J Med Life 3: 416-420. [Crossref]

162. Housa D, Vernerova Z, Heracek J, Cechak P, Rosova B, et al. (2008) Serum resistin levels in benign prostate hyperplasia and non-metastatic prostate cancer: possible role in cancer progression. Neoplasma 55: 442-446. [Crossref]

163. Hlavna M, Kohut L, Lipkova J, Bienertova-Vasku J, Dostalova Z, et al. (2011) Relationship of resistin levels with endometrial cancer risk. Neoplasma 58: 124-128. [Crossref]

164. Gonullu G, Kahraman H, Bedir A, Bektas A, Yucel I (2010) Association between adiponectin, resistin, insulin resistance, and colorectal tumors. Int J Colorectal Dis 25:205-12. [Crossref]

165. Nakajima TE, Yamada Y, Hamano T, Furuta K, Matsuda T, et al. (2010) Adipocytokines as new promising markers of colorectal tumors: adiponectin for colorectal adenoma, and resistin and visfatin for colorectal cancer. Cancer Sci 101: 1286-1291. [Crossref]

166. Kumor A, Daniel P, Pietruczuk M, Malecka-Panas E (2009) Serum leptin, adiponectin, and resistin concentration in colorectal adenoma and carcinoma (CC) patients. Int $J$ Colorectal Dis 24: 275-281. [Crossref]

167. Ilhan TT, Kebapcilar A, Yilmaz SA, Ilhan T, Kerimoglu OS, et al. (2015) Relations of Serum Visfatin and Resistin Levels with Endometrial Cancer and Factors Associated with its Prognosis. Asian Pac J Cancer Prev 16: 4503-4508. [Crossref]

168. Diakowska D, Markocka-Maczka K, Szelachowski P, Grabowski K (2014) Serum levels of resistin, adiponectin, and apelin in gastroesophageal cancer patients. Dis Markers 2014: 619649. [Crossref]

169. Assiri AM, Kamel HF, Hassanien MF (2015) Resistin, visfatin, adiponectin, and leptin: risk of breast cancer in pre- and postmenopausal saudi females and their possible diagnostic and predictive implications as novel biomarkers. Dis Markers: 253519. [Crossref]

170. Deshmukh SK, Srivastava SK, Bhardwaj A, Singh AP, Tyagi N, et al. (2015) Resistin and interleukin-6 exhibit racially-disparate expression in breast cancer patients, display molecular association and promote growth and aggressiveness of tumor cells through STAT3 activation. Oncotarget 6: 11231-11241. [Crossref]

171. Tsai CH, Tsai HC, Huang HN, Hung CH, Hsu CJ, et al. (2015) Resistin promotes tumor metastasis by down-regulation of miR-519d through the AMPK/p38 signaling pathway in human chondrosarcoma cells. Oncotarget 6: 258-270. [Crossref]

172. Hsieh YY, Shen CH, Huang WS, Chin CC, Kuo YH, et al. (2014) Resistin-induced stromal cell-derived factor-1 expression through Toll-like receptor 4 and activation of p38 MAPK/ NFkappaB signaling pathway in gastric cancer cells. J Biomed Sci 21: 59. [Crossref]

173. Zhao L, Wu F, Jin L, Lu T, Yang L, et al. (2014) Serum CXCL16 as a novel marker of renal injury in type 2 diabetes mellitus. PLoS One 9: e87786. [Crossref]

174. Xiao G, Wang X, Wang J, Zu L, Cheng G, et al. (2015) CXCL16/CXCR6 chemokine signaling mediates breast cancer progression by pERK1/2-dependent mechanisms. Oncotarget 6: 14165-14178. [Crossref]

175. Hald SM, Kiselev Y, Al-Saad S, Richardsen E, Johannessen C, et al. (2015) Prognostic impact of CXCL16 and CXCR6 in non-small cell lung cancer: combined high CXCL16 expression in tumor stroma and cancer cells yields improved survival. BMC Cancer 15: 441. [Crossref]

176. Mir H, Singh R, Kloecker GH, Lillard JW Jr, Singh S (2015) CXCR6 expression in non-small cell lung carcinoma supports metastatic process via modulating metalloproteinases. Oncotarget 6: 9985-9998. [Crossref]

177. Chalabi-Dchar M, Cassant-Sourdy S, Duluc C, Fanjul M, Lulka H, et al. (2015) Loss of Somatostatin Receptor Subtype 2 Promotes Growth of KRAS-Induced Pancreatic Tumors in Mice by Activating PI3K Signaling and Overexpression of CXCL16. Gastroenterology 148: 1452-1465. [Crossref]

178. Kee JY, Ito A, Hojo S, Hashimoto I, Igarashi Y, et al. (2014) CXCL16 suppresses liver metastasis of colorectal cancer by promoting TNF-Ît-induced apoptosis by tumorassociated macrophages. BMC Cancer 14: 949. [Crossref]

179. Zhang F, Huang W, Sheng M, Liu T (2015) MiR-451 inhibits cell growth and invasion by targeting CXCL16 and is associated with prognosis of osteosarcoma patients. Tumour Biol 36: 2041-2048. [Crossref]

180. Lee HS, Hong JE, Kim EJ, Kim SH (2014) Escin suppresses migration and invasion involving the alteration of CXCL16/CXCR6 axis in human gastric adenocarcinoma AGS cells. Nutr Cancer 66: 938-945. [Crossref]

181. Hu W, Liu Y, Zhou W, Si L, Ren L (2014) CXCL16 and CXCR6 are coexpressed in human lung cancer in vivo and mediate the invasion of lung cancer cell lines in vitro. PLoS One 9: e99056. [Crossref]

182. Fang Y, Henderson FC Jr, Yi Q, Lei Q, Li Y, et al. (2014) Chemokine CXCL16 expression suppresses migration and invasiveness and induces apoptosis in breast cancer cells. Mediators Inflamm 2014: 478641. [Crossref]

183. Gooden MJ, Wiersma VR, Boerma A, Leffers N, Boezen HM, et al. (2014) Elevated serum CXCL16 is an independent predictor of poor survival in ovarian cancer and may reflect pro-metastatic ADAM protease activity. Br J Cancer 110: 1535-1544. [Crossref]

184. Schmidt SV, Seibert S, Walch-Ruckheim B, Vicinus B, Kamionka EM, et al. (2015) RIPK3 expression in cervical cancer cells is required for PolyIC-induced necroptosis, IL-1alpha release, and efficient paracrine dendritic cell activation. Oncotarget 6 : 8635-8647. [Crossref]

185. Hong DS, Janku F, Naing A, Falchook GS, Piha-Paul S, et al. (2015) Xilonix, a nove true human antibody targeting the inflammatory cytokine interleukin-1 alpha, in nonsmall cell lung cancer. Invest New Drugs 33: 621-631. [Crossref]

186. Xu H, Hu MB, Bai PD, Zhu WH, Liu SH, et al. (2015) Proinflammatory cytokines in prostate cancer development and progression promoted by high-fat diet. Biomed Res Int 2015: 249741. [Crossref]

187. Dutcher JP, Neuberg D, Atkins MB, Tester WJ, Wadler S, et al. (2014) Report of phase I evaluation of dose and schedule of interleukin-1 alpha and cyclophosphamide in patients with advanced tumors: An Eastern Cooperative Oncology Group study 
(PX990) and review of IL-1-based studies of hematopoietic reconstitution. J Interferon Cytokine 34: 376-384. [Crossref]

188. Mannino MH, Zhu Z, Xiao H, Bai Q, Wakefield MR, et al. (2015) The paradoxical role of IL-10 in immunity and cancer. Cancer Lett 367: 103-107. [Crossref]

189. Oft M (2014) IL-10: master switch from tumor-promoting inflammation to antitumor immunity. Cancer Immunol Res 2: 194-199. [Crossref]

190. Sato T, Terai M, Tamura Y, Alexeev V, Mastrangelo MJ, Selvan SR (2011) Interleukin 10 in the tumor microenvironment: a target for anticancer immunotherapy. Immunol Res 51: 170-182. [Crossref]

191. Mocellin S, Marincola FM, Young HA (2005) Interleukin-10 and the immune response against cancer: a counterpoint. J Leukoc Biol 78: 1043-1051. [Crossref]

192. Teng MW, Darcy PK, Smyth MJ (2011) Stable IL-10: a new therapeutic that promotes tumor immunity. Cancer Cell 20: 691-693. [Crossref]

193. Colombo MP, Trinchieri G (2002) Interleukin-12 in anti-tumor immunity and immunotherapy. Cytokine Growth Factor Rev 13: 155-168. [Crossref]

194. Engel MA, Neurath MF (2010) Anticancer properties of the IL-12 family--focus on colorectal cancer. Curr Med Chem 17: 3303-3308. [Crossref]

195. Lasek W, Zagozdzon R, Jakobisiak M (2014) Interleukin 12: still a promising candidate for tumor immunotherapy? Cancer Immunol Immunother 63: 419-435. [Crossref]

196. Palma G, Barbieri A, Bimonte S, Palla M, Zappavigna S, et al. (2013) Interleukin 18: friend or foe in cancer. Biochim Biophys Acta 1836: 296-303. [Crossref]

197. Terme M, Ullrich E, Aymeric L, Meinhardt K, Desbois M, et al. (2011) IL-18 induces PD-1-dependent immunosuppression in cancer. Cancer Res 71: 5393-5399. [Crossref]

198. Fabbi M, Carbotti G, Ferrini S (2015) Context-dependent role of IL-18 in cancer biology and counter-regulation by IL-18BP. J Leukoc Biol 97: 665-675. [Crossref]

199. He XX, Chen K, Yang J, Li XY, Gan HY, et al. (2009) Macrophage migration inhibitory factor promotes colorectal cancer. Mol Med 15: 1-10. [Crossref]
200. Hussain F, Freissmuth M, Volkel D, Thiele M, Douillard P, et al. (2013) Human antimacrophage migration inhibitory factor antibodies inhibit growth of human prostate cancer cells in vitro and in vivo. Mol Cancer Ther 12: 1223-1234. [Crossref]

201. Babu SN, Chetal G, Kumar S (2012) Macrophage migration inhibitory factor: a potential marker for cancer diagnosis and therapy. Asian Pac J Cancer Prev 13: 17371744. [Crossref]

202. Oliveira CS, de Bock CE, Molloy TJ, Sadeqzadeh E, Geng XY, et al. (2014) Macrophage migration inhibitory factor engages $\mathrm{PI} 3 \mathrm{~K} / \mathrm{Akt}$ signalling and is a prognostic factor in metastatic melanoma. BMC Cancer 14: 630. [Crossref]

203. Ren Y, Cao B, Law S, Xie Y, Lee PY, Cheung L, et al. (2005) Hepatocyte growth factor promotes cancer cell migration and angiogenic factors expression: a prognostic marker of human esophageal squamous cell carcinomas. Clin Cancer Res 11: 61906197. [Crossref]

204. Kermorgant S, Aparicio T, Dessirier V, Lewin MJ, Lehy T (2001) Hepatocyte growth factor induces colonic cancer cell invasiveness via enhanced motility and protease overproduction. Evidence for PI3 kinase and PKC involvement. Carcinogenesis 22: 1035-1042. [Crossref]

205. Hultberg A, Morello V, Huyghe L, De Jonge N, Blanchetot C, et al. (2015) Depleting MET-Expressing Tumor Cells by ADCC Provides a Therapeutic Advantage over Inhibiting HGF/MET Signaling. Cancer Res 75: 3373-3383. [Crossref]

206. Li H, Zhang H, Zhao S, Shi Y, Yao J, et al. (2015) Overexpression of MACC1 and the association with hepatocyte growth factor/c-Met in epithelial ovarian cancer. Oncol Lett 9: 1989-1996. [Crossref]

207. Moazzam M, Ye L, Sun PH, Kynaston H, Jiang WG (2015) Knockdown of WAVE3 impairs HGF induced migration and invasion of prostate cancer cells. Cancer Cell Int 15: 51 . [Crossref]

208. Lech-Maranda E, Bienvenu J, Michallet AS, Houot R, Robak T, et al. (2006) Elevated IL-10 plasma levels correlate with poor prognosis in diffuse large B-cell lymphoma. Eur Cytokine Netw 17: 60-66. [Crossref]

Copyright: (C) $2016 \mathrm{Wu} \mathrm{Y.} \mathrm{This} \mathrm{is} \mathrm{an} \mathrm{open-access} \mathrm{article} \mathrm{distributed} \mathrm{under} \mathrm{the} \mathrm{terms} \mathrm{of} \mathrm{the} \mathrm{Creative} \mathrm{Commons} \mathrm{Attribution} \mathrm{License,} \mathrm{which} \mathrm{permits} \mathrm{unrestricted} \mathrm{use,}$ distribution, and reproduction in any medium, provided the original author and source are credited. 